\title{
ARTICULANDO CONHECIMENTOS CIENTÍFICOS E PRÁTICOS SOBRE ÁCIDOS/ BASES: UMA ANÁLISE DE FORMAS DE FALAR E MODOS DE PENSAR DE LICENCIANDOS EM QUÍMICA E CABELEIREIRAS
}

\author{
FLÁVIA CRISTIANE VIEIRA DA SILVA* \\ https://orcid.org/ 0000-0001-9044-6863 \\ EDENIA MARIA RIBEIRO DO AMARAL ${ }^{\| * *}$ \\ https://orcid.org/0000-0002-7945-6435
}

RESUMO: Este trabalho analisa formas de falar e modos de pensar sobre ácidos/bases a partir de significados construídos em duas situações distintas - na prática profissional de cabeleireiras, uma comunidade de prática, e na formação inicial de professores de química. A construção dos dados envolveu entrevistas individuais e semiestruturadas com cabeleireiras, e análise de relatórios e transcrição de falas de licenciandos quando relataram as suas interações com cabeleireiras, buscando identificar como elas compreendem ácidos/bases no contexto de tratamento capilar. Em geral, as cabeleireiras atribuem ao ácido sentidos não científicos associados a produtos para o cabelo usados na prática. No contexto acadêmico, foram identificados modos de pensar utilitarista/pragmático, substancialista, empirista, racionalista e relacional.

Palavras-chave: Ácido/base. Comunidades de práticas. Perfil conceitual.

\section{ARTICULANDO CONOCIMIENTOS CIENTÍFICOS Y PRÁCTICOS ACERCA DE LOS ÁCIDOS/BASES: UN ANÁLISIS DE LAS MANERAS DE HABLAR Y MODOS DE PENSAR DE ESTUDIANTES DE LA FORMACIÓN DOCENTE EN QUÍMICA Y PELUQUERAS}

RESUMEN: Este artículo analiza maneras de hablar y modos de pensar sobre los ácidos/bases desde significados construidos en dos situaciones distintas - en la práctica profesional de peluqueras, una comunidad de práctica, y en la formación inicial de profesores de química. Se llevó a cabo la recopilación de los datos a través de entrevistas individuales y semiestructuradas con peluqueras, y análisis de informes y transcripción de los discursos de

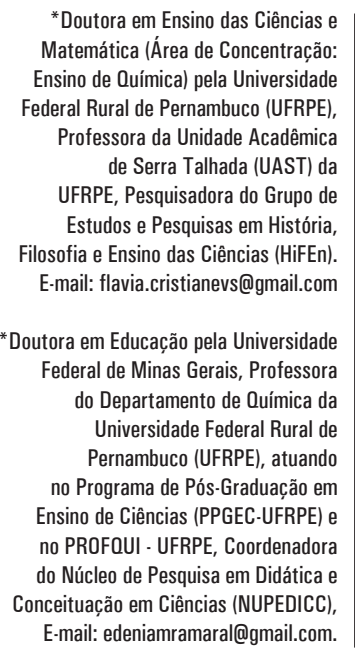

* Doutora em Ensino das Ciências e Ensino de Ouíca Federal Rural de Pernambuco (UFRPE), Professora da Unidade Acadêmica de Serra Talhada (UAST) da UFRPE, Pesquisadora do Grupo de osofia e Ensino das Ciências (HiFEn). E-mail: flavia.cristianevs@gmail.com

Doutora em Educação pela Universidade ederal de Minas Gerais, Professora o Departamento de Química da Universidade Federal Rural de Pernambuco (UFRPE), atuando Ensino de Ciências (PPGEC-UFRPE) e no PROFQUI - UFRPE, Coordenadora ceituação em Ciências (NUPEDICC), E-mail: edeniamramaral@gmail.com.

I Universidade Federal Rural de Pernambuco, Unidade Acadêmica de Serra Talhada, Serra Talhada - PE - Brasil.

II Universidade Federal Rural de Pernambuco, Departamento de Química, Recife - PE - Brasil. 
los estudiantes de Formación Docente cuando relataron sus interacciones con las peluqueras, buscando identificar cómo ellas entienden los ácidos/bases en el contexto del tratamiento capilar. En general, las peluqueras atribuyen al ácido sentidos no científicos asociados con productos para el pelo utilizados en la práctica. En el contexto académico, se identificaron modos de pensar utilitarista/pragmático, sustancialista, empirista, racionalista y relacional.

Palabras clave: Ácido/base. Comunidades de prácticas. Perfil conceptual.

\section{ARTICULATING PRACTICAL AND SCIENTIFIC KNOWLEDGES ON ACIDS/BASES: ANALYSIS OF WAYS OF SPEAKING AND THINKING FROM LICENSED CHEMISTRY TEACHERS AND HAIRDRESSERS}

ABSTRACT: This work analyzes ways of speaking and thinking on acids/bases from the meanings built in two different situations - the professional practice of hairdressers, a community of practice, and a formation course for Chemistry teachers. We collected data from individual semi-structured interviews conducted with hairdressers and the analysis of licensed teachers' reports and speeches transcriptions on interviews that they performed with hairdressers, aiming to identify how they understand acids/bases in the context of hair treatment. In general, the hairdressers expressed unscientific ideas on acid associated with the use of hair products in practice. In the academic context, utilitarian/pragmatic, substantialist, empirical, rationalistic and relational ways of thinking were identified.

Keywords: Acids/bases. Communities of practice. Conceptual profile. 


\section{INTRODUÇÃO}

O presente trabalho apresenta uma análise de diferentes modos de pensar associados a formas de falar sobre o conceito de ácido/base que emergem em dois grupos distintos - sujeitos que participam de uma comunidade de prática e estudantes do curso de licenciatura em química - visando compreender como se articulam conhecimentos práticos e científicos em dois contextos distintos. Para isso, tomamos por base duas perspectivas teóricas: o perfil conceitual e uma perspectiva de aprendizagem por participação social em comunidades de prática. Com isso, buscamos analisar diferentes modos de pensar sobre ácidos/bases para compreender como o conhecimento científico é usado (ou não) em contextos diferentes da sala de aula e como sentidos construídos em comunidades de prática estão relacionados com a visão científica para esse conceito.

No ensino de química, o conceito de ácido/base é apresentado por meio de diversos modelos explicativos baseados em teorias que surgiram ao longo do desenvolvimento histórico da ciência. No Ensino Médio, em geral, ácidos e bases são abordados a partir de teorias propostas por Arrhenius, Brønsted-Lowry e Lewis. Os termos ácido e básico (alcalino) também estão relacionados com situações não escolares, fazendo parte da linguagem cotidiana e/ou linguagem específica de atividades profissionais associadas a diferentes contextos sociais e/ou profissionais. Por exemplo, no uso doméstico de materiais de limpeza, muitos se referem ao ácido muriático; na sensação de azia (acidez estomacal) são mencionados os antiácidos; acidez ou adstringência associada a alimentos, ou ainda, ao uso de produtos ácidos ou alcalinos relacionados com tratamento estético ou capilar.

Neste trabalho, serão abordados dois contextos nos quais os sujeitos participantes negociam e constroem significados sobre o conceito de ácido/base: estudantes de licenciatura em química e um grupo de cabeleireiras de uma mesma cidade, consideradas aqui como uma comunidade de prática. As comunidades de prática são definidas por Wenger (1998) como grupos de pessoas que se engajam em uma prática compartilhada, com focos comuns, e que aprendem por meio da participação. Nessas comunidades, as práticas são organizadas a partir de diferentes modos de ver e pensar o mundo, o que possibilita aos sujeitos participantes construir significados e refletir sobre essas práticas.

\section{COMUNIDADESDE PRÁTICAE PERFISCONCEITUAIS: ARTICULANDO PERSPECTIVAS DE SIGNIFICAÇÃOO E APLICAÇ̃̃O DOS DIFERENTES MODOS DE PENSAR O CONCEITO DE ÁCIDO/BASE}

Comunidades de prática são grupos de pessoas com uma preocupação em comum, um conjunto de problemas ou uma paixão a respeito de algum tópico, e que aprofundam seus conhecimentos e expertise por meio da participação em uma prática compartilhada (WENGER, 1998). Os diferentes modos de ver e pensar sobre o mundo conduzem a prática na comunidade, na qual cada indivíduo constrói um conjunto de conhecimentos e a sua identidade, ressignificando, negociando e desenvolvendo teorias em torno da prática que mantém a comunidade viva. Para 
Wenger (1998), comunidades de prática só fazem sentido quando os dois termos são usados associadamente, os termos comunidade e prática integram-se para definir um tipo especial de comunidade na qual há o compartilhamento de três elementos fundamentais, nomeadamente: domínio, comunidade e prática.

Domínio é o conhecimento criado por uma comunidade de praticantes, que não apresenta fronteira definida nem se define como tal, mas identifica essa comunidade diferenciando os seus membros entre si e daqueles que pertencem a outras comunidades. Pode-se dizer que o domínio é o tema ou conjunto de temas de interesse de uma determinada comunidade. Cyrino e Caldeira (2011) afirmam que o domínio cria uma base comum de conhecimentos, definindo a identidade da comunidade, e não é algo fixo, mas acompanha as mudanças do mundo e da comunidade, a partir de novos problemas, desafios e perspectivas.

Comunidade é o que se constitui a partir de relações requeridas pela ação conjunta e repetida realizada no ato de produzir, sendo formada por membros que se comprometem a trocar informações sobre o assunto do seu domínio, ou entram em contato com informações próprias da comunidade que faz parte (WENGER, 1998). Segundo o autor, a prática é projetada pelo compartilhamento dos significados da ação efetuada, produzindo uma identidade que define a comunidade. Os membros estão dispostos a estudar e/ou resolver problemas, desenvolver recursos, instrumentos, linguagem, conforme o seu domínio. Eles compartilham modos de pensar, conhecimentos específicos construídos e mantidos pela comunidade (CYRINO e CALDEIRA, 2011), e um repertório de experiências, histórias, formas de abordar e resolver problemas recorrentes (COLL, BUSTOS e ENGEL, 2010).

A partir das ideias de Wenger (1998), buscamos compreender como pessoas que se envolvem em uma mesma prática compartilham experiências vividas e aprendizagens adquiridas, de forma que se reconheçam como membros de um grupo ou comunidade. Como essas pessoas acessam um ou outro modo de pensar para uma comunicação eficaz. Para indivíduos de um mesmo grupo social, ou de uma mesma comunidade, a forma de lidar com determinada situação pode ocorrer de modo semelhante, devido aos significados que são negociados pelos membros. Para atender aos objetivos deste trabalho, escolhemos um tema relacionado com o conceito de ácido/base e buscamos compreender o domínio construído por um grupo de cabeleireiras, que diariamente lidam com produtos cujas características de acidez e basicidade são importantes para o tratamento capilar. Verificamos que essas profissionais compartilham um repertório de conhecimentos, experiências, técnicas e ferramentas na sua prática profissional, e têm como objetivo comum ofertar serviços de tratamento e embelezamento capilar. Na vivência dessa prática, diferentes modos de pensar sobre ácido/base fazem parte da comunidade de prática.

Existem diferentes formas de falar sobre ácidos e bases, utilizadas por sujeitos e elas podem estar associadas a diferentes modos de pensar sobre esse conceito, que podem ser caracterizados e estruturados a partir da teoria do perfil conceitual. Perfis conceituais podem ser considerados como modelos que estruturam modos diferentes de ver e conceituar o mundo, usados pelos indivíduos para significar a sua experiência (MORTIMER et al., 2014). A teoria dos perfis conceituais se fundamenta na ideia de que uma diversidade de significados pode ser atribuída a um conceito, sendo aplicada em diferentes contextos e, com isso, 
um indivíduo pode exibir diferentes modos de pensar sobre um dado conceito, representando de forma distinta uma mesma realidade (AMARAL e MORTIMER, 2004; ARAÚJO e MORTIMER, 2012). Amaral e Mortimer (2004) chamam a atenção para o fato de que diferentes modos de pensar sobre a realidade estão associados a contextos específicos que lhes são apropriados, não considerando uma ou outra forma melhor para qualquer contexto.

Em um perfil conceitual, os diferentes modos de pensar são organizados em zonas que representam compromissos epistemológicos, ontológicos e axiológicos distintos (MORTIMER et al, 2014). Cada zona corresponde a uma visão de mundo diferente, na qual o indivíduo acessa a realidade a partir de meios mediacionais que lhes são próprios (SILVA, 2011). Assim, um indivíduo pode expressar diferentes modos de pensar sobre o conceito de ácido/base, dependendo do contexto em que esteja inserido, o que indica que em cada indivíduo pode existir uma heterogeneidade de pensamento. No entanto, também consideramos as zonas do perfil como supra individuais e sociais, uma vez que refletem modos de pensar e de significar a experiência, que são impostos à cognição individual ao longo de seu processo de formação (MORTIMER, SCOT'T e EL-HANI, 2011).

Neste trabalho, buscamos organizar os diferentes modos de pensar e formas de falar a partir de zonas propostas para o perfil conceitual de substância (SILVA, 2011; 2017), uma vez que ácidos e bases podem ser considerados como categorias de substâncias químicas caracterizadas por propriedades atribuídas às mesmas.

\section{PERFIL CONCEITUAL DE SUBSTÂNCIA E SEU POTENCIAL USO PARA O ESTUDO DE ÁCIDOS/BASES}

Silva (2011) propôs um perfil conceitual de substância composto por cinco zonas: generalista, essencialista, substancialista, racionalista e relacional. Algumas dessas zonas foram ampliadas ou redefinidas em trabalhos recentes (SILVA, 2017; SABINO e AMARAL, 2018). Silva (2017), ao discutir aspectos históricos do conceito de substância, e Sabino e Amaral (2018), ao analisarem a emergência dessa zona na sala de aula, verificaram ideias agrupadas nas zonas generalista e essencialista pareciam estar associadas a compromissos semelhantes. Dessa forma, consideramos aqui, as zonas atualizadas para o perfil de substância: generalista, utilitarista/pragmática, substancialista, racionalista e relacional.

Nazonageneralista, estãoincluídas concepções de substância, compreendida como algo que está em toda a parte - tudo é substância ou há substância em tudo, em todos os materiais, sem que seja apresentado qualquer esforço de diferenciação entre elementos, substâncias e materiais. Além disso, nessa zona, estão ideias de substância enquanto essência ou propriedade essencial dos materiais. Algumas ideias que se referem à aplicação e uso das substâncias considerando que elas podem ter finalidade ou uso para a vida, e que são atribuídos valores sobre benefícios e/ou malefícios causados às pessoas, outros seres vivos e ao ambiente (compromissos axiológicos), foram agrupadas em uma nova zona denominada de utilitarista/pragmática (SILVA, 2017). Na zona substancialista, estão concepções em que a compreensão das substâncias está associada a uma substancialização das partes e do todo. Por exemplo, propriedades da substância são estendidas 
aos átomos ou moléculas constituintes, e/ou a substância é identificada com o próprio material, sem que seja feita distinção entre propriedades do material e dos seus constituintes (SILVA, 2011; SILVA e AMARAL, 2013). A zona racionalista inclui concepções que representam os níveis macroscópico e atômico molecular para a compreensão de substância. No nível macroscópico, temos a caracterização das substâncias pelas propriedades, consideradas como fatores determinantes na identificação e diferenciação de substâncias, de forma que essas propriedades são consideradas invariáveis e exclusivas para cada uma delas (SILVA, 2011; SILVA e AMARAL, 2013). No nível atômico molecular, é apresentada uma compreensão de substância a partir das ideias de átomo, elemento ou molécula. Essas ideias são consideradas a partir de um compromisso racionalista, no qual modelos explicativos justificam o conceito científico. E, finalmente, a zona relacional inclui um nível de compreensão mais complexo, no qual as relações das substâncias entre si, com o meio e com a energia são determinantes para a compreensão do conceito. As propriedades são vistas como um jogo relacional e não como parâmetros completamente definidos (SILVA, 2011; SILVA e AMARAL, 2013).

Como colocado anteriormente, ácidos/bases são categorias ou atribuições dadas para substâncias químicas. Dessa forma, concepções sobre ácido/base foram analisadas tendo como apoio as zonas do perfil conceitual de substância, considerando as modificações feitas no perfil por Silva (2017), e propondo novas adequações. No quadro 1, são mostrados modos de pensar sobre o conceito de ácido/base usados na análise de dados. E, para uma melhor compreensão do que estamos considerando em cada modo de pensar, incluímos alguns exemplos de concepções encontrados na literatura.

Quadro 1. Estruturando diferentes modos de pensar sobre ácido/base a partir do perfil de substância.

\section{Modos de pensar sobre ácido/base}

GENERALISTA: Não há distinção entre o que se entende por substância ácida, elementos que constituem ácidos, meio ácido, produto ácido, solução ácida. Características e propriedades ácidas ou alcalinas são consideradas como um todo nos sistemas e produtos, sem a percepção de que alguns dos seus componentes possam ser responsáveis por elas.

Exemplos: “A gente sabe que o elemento é ácido, quando por ex. $\mathrm{HCl}$ - ácido clorídrico $(\mathrm{H}$ no início)"; (FIGUEIRA et al, 2009). “Ácidos são compostos que são altamente perigosos dependendo da sua composição, não sei bem a sua definição, mas ácidos são aquilo que é perigoso". (SILVA e AMARAL, 2014).

UTILITARISTA/PRAGMÁTICO: Ácidos/bases são identificados como algo que possui utilidade e finalidade, estão presentes em situações/atividades do cotidiano e podem causar malefícios/ benefícios aos seres humanos.

Exemplos: “Ácido, qualquer pingo que ele tocar em qualquer lugar de sua parte ele queima"; “o ácido é um verdadeiro veneno, é muito é tóxico, (...) e é porque está junto de outros materiais, mas eu digo a você que é um perigo" (SILVA, 2017b).

SUBSTANCIALISTA: Ácidos/bases estão contidos nos materiais, mas não é feita distinção entre aspectos macroscópicos e atômico moleculares de ácidos/bases, propriedades ácido/ base são transferidas para os constituintes e o todo, e há a visão de que acidez/basicidade se refere a um todo e não a um componente.

Exemplos: “É um composto corrosivo e também está presente em alguns alimentos"; “É uma substância forte, corrosiva"; "Substância que ataca o mármore”, “ácidos são substâncias corrosivas" (BADARCA,; NIETO e RODRIGREZ, 1993; GOMES e ALADARES, 2004; OLIVEIRA, 2008). 
RACIONALISTA MACROSCÓPICO: Ácidos/bases são substâncias definidas a partir de propriedades macroscópicas - físicas, químicas ou organolépticas.

Exemplos: "São líquidos que corroem e geralmente são azedos", "Possuem gosto, são corrosivos, uns mais que outros", "Podem ser fracos ou fortes, com poder de corrosão" (FIGUEIRA e ROCHA, 2011), "Ácido: sabor azedo estimula a secreção salivar, conduz corrente elétrica" (CARDOSO, SILVA e LIMA, 2014).

RACIONALISTA ATÔMICO MOLECULAR: Ácidos/bases são caracterizados pela presença de entidades, constituintes ou configurações químicas específicas, tais como, íons $\mathrm{H}^{+}$e $\mathrm{OH}^{-}$em solução, presença de $\mathrm{H}$ ionizável na estrutura molecular, íon $\mathrm{H}^{+}$e pares de elétrons doados ou recebidos.

Exemplos: "São compostos que apresentam o átomo de hidrogênio como o primeiro elemento, exceto a água"; "São substâncias com H+(..)". (BARDANCA, NIETO e RODRIGUEZ, 1993; OLIVEIRA, 2008; FIGUEIRA et al, 2009); "São substâncias químicas compostas por H+"; "São substâncias que contêm H+ em sua fórmula" (FIGUEIRA e ROCHA, 2011); "Ácido libera $\mathrm{H}+$ e base libera OH-." (CARDOSO, SILVA e LIMA, 2014); "ácido pra mim tá relacionado com uma substância que ao ser ionizada é... em solução ela vai ter o íon hidrônio, esse íon é... estando mais ou menos concentrado (SILVA e AMARAL, 2014).

RELACIONAL: 0 caráter ácido/base é compreendido a partir de condições estabelecidas e/ou de interações entre substâncias, ou delas com o meio, e seus aspectos energéticos.

Exemplos: "No ensino médio, a gente identifica aqueles que tem hidrogênio no início. $A$ gente identifica ácidos como aqueles que doam próton, (...) eu penso num ácido que está no cotidiano e eu também penso num ácido quando ele está protonado, que não deixa de ser um ácido (...) penso também na água que ela se comporta ou como ácido ou como base. ISILVA e AMARAL, 2014).

EMPIRISTA: Concepção de ácido/base usando a medida do $\mathrm{pH}$ ou da escala de $\mathrm{pH}$; o pH determina o caráter ácido/básico/neutro de substâncias e materiais.

Exemplos: "Substâncias que possuem pH menor que 7,0"; "São substâncias capazes de liberar $\mathrm{H+}$ em solução aquosa. Possuem pH entre 1 e 6, pois o pH 7 já é neutro" (FIGUEIRA e ROCHA, 2011). São substâncias que têm o pH abaixo de 7, entre 0 e 6,9 são alcalinos;" $p H$ abaixo de 7 é ácido" (SILVA e AMARAL, 2014).

Fonte: Baseado em Silva e Amaral, 2013 e Silva, 2017.

No quadro 1, podemos verificar uma estruturação de diferentes modos de pensar sobre ácido/base, que foram associados a zonas do perfil conceitual de substância (SILVA e AMARAL, 2013; SILVA, 2017) considerando os compromissos epistemológicos, ontológicos e axiológicos implicados nessas zonas. Um modo de pensar generalista sobre ácido/base está relacionado com a compreensão indistinta das propriedades ácidas ou básicas de materiais, substâncias e meios ou soluções. Ou seja, o caráter ácido/básico não necessariamente é atribuído a uma substância, mas ao todo e isso parece ter relação com uma compreensão generalista da própria substância. Um modo de pensar utilitarista/pragmático sobre ácido/base, tal como na compreensão da substância, se relaciona com finalidades e usos de produtos, e com benefícios ou malefícios que eles podem causar aos seres humanos e ao ambiente. Por exemplo, podem ser incluídos problemas causados pela ingestão excessiva de alimentos com acidez elevada, a acidez/basicidade não controlada de mares e rios, o contato com produtos ácidos que podem causar queimaduras e irritação. Um modo de pensar substancialista traz a compreensão de que ácidos/bases estão contidos em materiais, sendo as suas propriedades transferidas para todo o material, ou ainda, que substâncias contêm propriedades ácidas/básicas, ou seja, esses seriam atributos intrínsecos das substâncias e não consequência de suas interações com o meio. Por 
exemplo, a propriedade ácida atribuída ao cloreto de hidrogênio, só é verificada quando essa substância interage com a água e os íons $\left(\mathrm{H}^{+} \mathrm{e} \mathrm{Cl}^{-}\right)$estão dispersos no meio aquoso, não sendo uma característica inerente da substância.

Quando a explicação do comportamento ácido ou básico das substâncias é apresentada em uma dimensão atômico molecular, podemos considerar que a compreensão sobre ácido/base chega aos modelos explicativos da ciência química, e assume um compromisso racionalista. Nesse modo de pensar, o comportamento ácido/base pode ser explicado por modelos que envolvem produção ou transferência de prótons $\mathrm{H}^{+}$(teorias de Arrhenius e de Brönsted-Lowry) ou de pares eletrônicos (teoria de Lewis). E com isso, torna-se possível diferenciar tipos de ácidos/bases a partir da sua constituição ou configuração. Esse é um modo de pensar racionalista, que se expressa em uma dimensão atômico molecular. Ele também pode se expressar em uma dimensão macroscópica, quando são apresentadas propriedades características das substâncias que apresentam comportamento ácido/base - propriedades físicas, químicas ou organolépticas - tais como sabor azedo (em referência a alimentos ácidos), poder de corrosão, neutralização, etc. Sabino e Amaral (2018) também estruturaram as ideias sobre substância, considerando dimensões macroscópicas, em uma zona distinta das ideias que abordam as substâncias a partir de suas características atômico moleculares, tomando como base o trabalho de Silva (2017).

O modo de pensar relacional é representativo de uma compreensão mais complexa sobre o caráter ácido/base de substâncias quando considera as condições e interações nas quais essas substâncias se comportam como ácidos e bases, não sendo essa uma propriedade inerente das mesmas.

Para a análise dos modos de pensar associados ao conceito de ácido/base que emergiram neste trabalho, propomos ainda a inclusão de um modo de pensar sobre ácido/base, no qual a medida do potencial hidrogeniônico $(\mathrm{pH})$ se torna um parâmetro que define a acidez/basicidade das substâncias e materiais. Uma escala de $\mathrm{pH}$ é usada para separar, em um contínuo de 1 a 14, os comportamentos ácidos $(\mathrm{pH}<7)$, básicos/alcalinos $(\mathrm{pH}>7)$ e neutros $(\mathrm{pH}=7)$ de sistemas, e a determinação empírica do $\mathrm{pH}$ é usada para definir ácidos e bases, constituindo um compromisso empirista ao modo de pensar esse conceito. Uma zona empírica foi identificada por Amaral e Mortimer (2001), na proposição do perfil conceitual de calor, quando este conceito era reconhecido pela medida de temperatura. Para os autores, a zona empírica do perfil de calor estava relacionada com as medidas de temperatura feitas em termômetros, para dimensionar quantidades e fluxos de calor.

Para analisar diferentes formas de falar que podem estar associadas a modos de pensar sobre ácidos e bases, nos contextos da prática profissional de cabeleireiras e da licenciatura em química, consideramos as ideias de Lemke (1997), que serão discutidas posteriormente. O autor defende que a aprendizagem em ciências está diretamente associada com a aprendizagem da linguagem especializada da ciência, incluindo aspectos referentes a ler, escrever, interpretar e resolver problemas, com mediação dessa linguagem. Nesse sentido, acreditamos ser possível identificar quais modos de pensar sobre o conceito de ácido/base emergem nos grupos investigados, a partir da análise de relações semânticas entre itens temáticos utilizados por cada grupo. 


\section{METODOLOGIA}

Esta pesquisa adota uma abordagem metodológica qualitativa, por considerar que o objetivo proposto demanda um exercício de interpretação dos pesquisadores, que têm papel relevante no processo investigativo (ANDRÉ, 2001). Os dados analisados foram construídos em duas etapas. Na primeira etapa, foram realizadas entrevistas semiestruturadas individuais com 7 cabeleireiras que apresentavam diferentes perfis de experiência e atuavam na cidade de Serra Talhada, Pernambuco. Buscamos identificar, nas falas das entrevistadas, como elas organizam sua prática em torno de situações envolvendo ácidos, ${ }^{1}$ analisando que sentidos são atribuídos a esse conceito. As entrevistas foram gravadas em áudio e transcritas para análise, as questões que orientaram a entrevista foram: No seu dia a dia, você lida com ácidos? Em que situações ou com que finalidade você lida com ácidos? O que você entende por ácidos? Você trabalha verificando o pH de alguns produtos? Como o pH orienta os procedimentos? O que você entende por $\mathrm{pH}$ ? Vocês observam o $\mathrm{pH}$ do shampoo? De que forma o $\mathrm{pH}$ do shampoo interfere no cabelo? Por exemplo, como funciona a (escova) progressiva a base de ácido glioxílico? E de que forma o ácido age no cabelo? Qual a ação do shampoo antirresíduo? E que relação ele tem com os ácidos? Como age a amônia usada para alisamento? Existe diferença com relação à ação do ácido glioxílico?

$\mathrm{Na}$ segunda etapa, os dados foram construídos a partir de um questionário sobre a temática ácido/base (1- Em que situações ou com que finalidade você lida com ácidos? $\mathrm{E}$ com as bases? 2 - O que você entende por ácido? O que você entende por base? Como você representaria um ácido/base? 3 - Como os ácidos/bases estão presentes nos contextos de: a) ambientalistas; b) cabeleireiras; c) dermatologistas; d) aula de química do ensino médio) e uma sequência didática organizada no formato de módulo de formação, intitulado "Estudo de caso no ensino de química: uma vivência sobre a temática química do cabelo". No estudo de caso, foi relatada uma situação na qual a cliente de um salão de beleza apresentou um problema de queda de cabelo, provavelmente ocasionado pelo uso indevido de produtos químicos diferentes em tratamentos capilares sucessivos, nos quais a acidez e a basicidade têm um papel importante na conduta adotada por cabelereiros. O estudo de caso foi elaborado pela pesquisadora com base em um fato real relatado pelas cabeleireiras durante as entrevistas. Participaram da pesquisa 22 licenciandos em química que eram bolsistas do Programa Institucional de Bolsa de Iniciação à Docência, da Universidade Federal Rural de Pernambuco/ Unidade Acadêmica de Serra Talhada (PIBID-UFRPE/UAST).

Para buscar explicações e soluções sobre o caso apresentado, os licenciandos trabalharam em grupos e uma das atividades propostas na sequência foi a elaboração de questões para realização de entrevistas com profissionais que atuam em salão de beleza. As questões deveriam ter como objetivo buscar informações adicionais para solucionar o caso. A pesquisadora solicitou que cada grupo elaborasse um relatório escrito para registro e organização dos dados construídos na entrevista e fizesse uma apresentação dos resultados para todo o grupo. As apresentações dos grupos foram gravadas em vídeo/áudio e transcritas. Neste trabalho, para a análise, consideramos as questões formuladas 
pelos licenciandos para a entrevista e os relatórios apresentados pelos grupos, de modo a identificar modos de pensar e formas de falar sobre ácidos e bases que circularam na interação entre cabeleireiras e licenciandos.

Para compreender a relação entre os significados das palavras, Lemke propõe o uso de uma ferramenta denominada diagrama temático, que é uma forma de representar graficamente o padrão temático produzido em interações discursivas sobre um tópico da ciência. No nosso caso, analisaremos as falas produzidas pelas entrevistadas e os relatórios apresentados por licenciandos sobre entrevistas propostas e realizadas por eles a outras cabeleireiras. Segundo Lemke (1997), o padrão temático é a forma como um grupo fala sobre um tema. Esse padrão é composto por itens temáticos, elementos que podem ser expressos de diferentes formas, por exemplo, som, ondas de som, vibrações, que expressam a mesma coisa. Os diferentes itens temáticos guardam entre si relações semânticas. De acordo com o autor, as palavras podem ser usadas de formas diferentes para construir as relações semânticas, constituindo diferentes formações temáticas.

Lemke (1997) destaca que cada grupo ou categoria social elabora diferentes significados, a partir de diferentes estruturas de atividades, distintas formações temáticas e diversas maneiras de utilizar essas formações. A forma como uma pessoa fala sobre um tema, pode diferenciá-la ou incluí-la em um grupo social. $\mathrm{Na}$ medida em que os sujeitos participam de uma comunidade, e aquilo que se fala não é diferente do que normalmente ocorre na experiência dos seus membros, a tendência é chegar ao mesmo padrão de significados. No entanto, pode haver diferenças nos padrões devido a questões relacionadas com teorias, opiniões, sistemas de valores, que podem ser diferentes para uma parcela de membros. Neste trabalho, a partir da análise das relações semânticas que compõem os diagramas temáticos, identificamos formas de falar que associamos a modos de pensar utilizados pelos dois grupos para significar suas experiências.

As relações semânticas foram identificadas, entre várias categorias propostas por Lemke (1997): portador/atributo (por/atr) - há uma relação que confere atributos de um para outro item temático; agente/processo (ag/proc) - os itens se relacionam entre si identificados como agente e processo; coisa/ classificador (co/clas) - a relação entre os itens temáticos representa algum tipo de classificação; parte/todo (prt/td) - a relação entre os itens temáticos sugere pertencimento ou complementação de um para com o outro; tipo/mostra (tp/ mo) - a relação entre os itens sugere uma identificação ou amostragem de tipos.

Neste trabalho, por questões de espaço, apresentamos a análise das entrevistas de duas cabeleireiras, Mariana e Marília (nomes fictícios), entrevistadas pela primeira autora desse artigo. As duas entrevistas foram escolhidas por serem representativas do conjunto de ideias obtidas no conjunto de entrevistas realizadas, e contemplam uma cabeleireira mais experiente e, outra, no início da atividade profissional. Padrões temáticos foram construídos para cada uma das cabeleireiras. Quanto aos licenciandos de química, analisamos as respostas a duas perguntas feitas no questionário (questões semelhantes àquelas feitas às cabeleireiras, nas entrevistas: "O que você entende por ácido? O que você entende por base?"). Aqui, apresentamos as respostas de 2 licenciandos, para os quais também foram construídos diagramas temáticos, e analisamos os relatórios e apresentação de 2 
grupos de licenciandos sobre as entrevistas realizadas com as cabeleireiras, sendo esses dados representativos do conjunto.

\section{RESULTADOS E DISCUSSÃO}

Os resultados serão apresentados primeiro considerando o contexto das cabeleireiras, seguido da análise das respostas dos licenciandos ao questionário e, finalmente, a análise das questões e relatórios das entrevistas apresentados pelos licenciandos.

\subsection{Analisando modos de pensar sobre ácido/base expressados pelas cabeleireiras}

Inicialmente, é importante destacar que o grupo de cabeleireiras foi identificado como uma comunidade de prática a partir dos elementos descritos por Wenger (1998)-domínio, comunidade e prática. Nas entrevistas, foi possível perceber que há um domínio compartilhado por todas as cabeleireiras, o que diferencia esse grupo de outros grupos profissionais: todas já enfrentaram problemas/situações no cotidiano do seu trabalho que a fizeram buscar soluções a partir do que parece se constituir como domínio para a comunidade: recursos, ferramentas e conhecimentos aprendidos na prática com o tratamento de cabelos; conhecimentos adquiridos nas trocas de experiências e em apresentações de produtos por representantes de marcas comerciais. No contato com as cabeleireiras, ficou evidente que todas adquirem conhecimentos de forma situada, a partir do engajamento na prática, em cursos profissionais, durante atuação profissional, ou com cabeleireiras mais experientes. $\mathrm{Na}$ transcrição das entrevistas, foram considerados trechos em que os termos ácido e $\mathrm{pH}$ apareciam na pergunta ou nas respostas, sendo identificados itens temáticos relacionados com esses termos. De acordo com Lemke (1997), o item temático é uma palavra ou frase usada para se falar de um tema particular. Itens temáticos foram destacados em negrito nas transcrições e posteriormente organizados em um diagrama. No diagrama, foram destacadas relações semânticas estabelecidas entre itens temáticos a partir de atributos propostos por Lemke (1997), o que possibilitou a identificação de modos de pensar.

$\mathrm{Na}$ entrevista, a cabeleireira Mariana afirmou ter aberto o salão há cerca de um ano e que atuava na área informalmente, fazendo procedimentos no próprio cabelo, no cabelo das amigas e de familiares, que a encorajaram a abrir seu próprio estabelecimento. Para isso, procurou um curso profissional que, segundo ela, não foi concluído porque ela considerava que já sabia realizar grande parte dos procedimentos relacionados ao tratamento capilar. Mariana frequentava curso superior na área de Ciências da Natureza, o que provavelmente justificava o fato de ter sido a única entre as entrevistadas a relacionar o ácido com o termo substância, conforme podemos ver nos trechos de sua entrevista, no quadro 2. A pergunta feita pela pesquisadora $(\mathrm{P})$ está em itálico e os itens temáticos estão em negrito. 
Quadro 2. Transcrição de falas e itens temáticos na entrevista com a cabeleireira Mariana (M).

\section{Trechos de falas da cabeleireira Mariana na entrevista}

P: Você lida com ácidos no seu dia a dia?

M: Só a questão da progressiva mesmo ou uma hidratação profunda que de vez em quando ele vem (...) uma quantidade de alguma coisa.

P: Qual é a finalidade especificamente desses produtos?

M: Da progressiva é alisar né, dar hidratação/ o que tem alguma coisa assim um ácido (...), é mais para deixar o cabelo mais leve, menos pesado com mais, como é que se diz? Mais leveza aí tem que ser (...) bem potente.

M: (...) o ácido pelo que eu entendo, é assim a substância de algum produto (...) é uma substância que é colocada dentro do produto".

P: E aí, a função dos ácidos no cotidiano do seu trabalho é basicamente essa?

M: É, para hidratar o cabelo pra deixar mais leve, menos volumoso, para fechar mais as cutículas do cabelo essas coisas assim, para tirar o quebrado/ tem deles que até 0 ressecado ele diminui ele tira (...).

M: (...) se ele é neutro se ele é básico se é ácido se ele é neutro, eu sempre olho. Meus produtos geralmente o pH não passa de sete, porque se passou ele já é mais agressivo para o cabelo é muito mais forte.

M: Pelo que eu entendo um pouco, o ácido se torna agressivo pro cabelo, não só para o cabelo como para qualquer parte do corpo, quanto mais ácido mais agressivo ele se torna né?

P: 0 que seria $\mathrm{pH}$ ?

M: eu sei que é menos de sete é básico, mais de sete é ácido e sete é neutro.

Fonte: Dados da pesquisa

No Quadro 2, destacamos em negrito alguns itens temáticos na entrevista de Mariana, e a partir desses itens temáticos, buscamos identificar relações semânticas para construir um diagrama de padrão temático para a cabeleireira. Um padrão temático representativo das ideias apresentadas pela cabeleireira Mariana.

O diagrama da figura 1, construído a partir da análise da entrevista da cabeleireira Mariana, mostra que há relações semânticas distintas entre os diferentes itens temáticos, destacados no Quadro 2:

Figura 1. Diagrama de Padrão Temático da cabeleireira Mariana

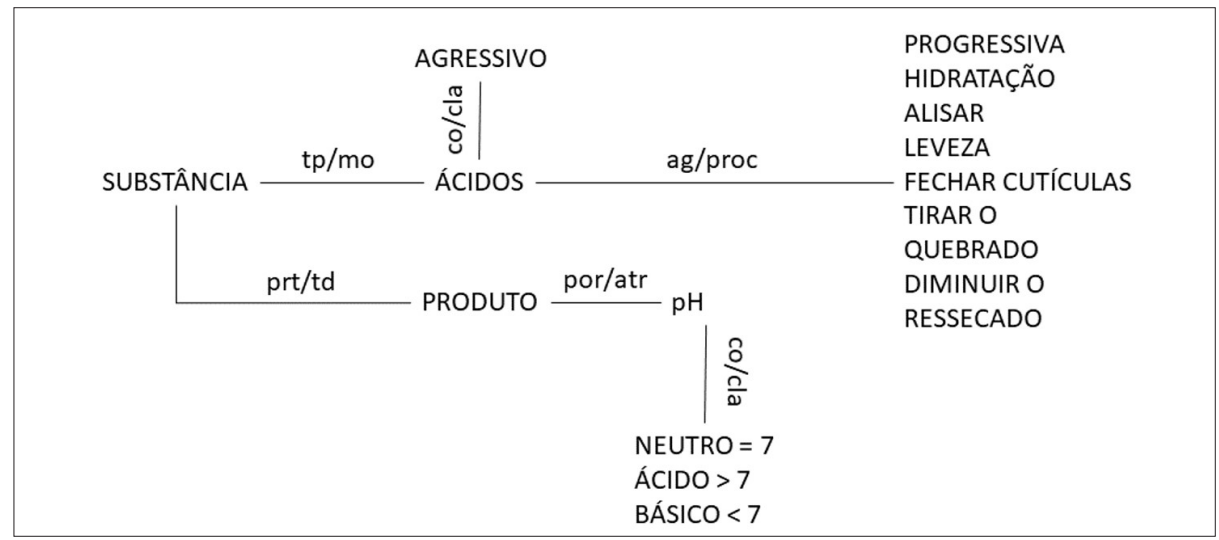

Fonte: Dados da pesquisa, Legenda: por/atr: portador/atributo; ag/proc: agente/processo; co/cla: coisa/classificador; prt/td: parte/todo; tp/mo: tipo/mostra. 
Primeiramente, é possível perceber relações semânticas que associam ácidos a procedimentos realizados no cotidiano dos salões de beleza, entre eles, a escova progressiva e a hidratação profunda dos cabelos. Não há a identificação clara dos ácidos nos produtos usados, o que sugere a expressão também de um modo de pensar generalista. Por outro lado, a cabeleireira deixou claro que se o ácido for "forte" ele pode se tornar agressivo ao cabelo, identificando-o como um tipo de substância que está presente em diferentes produtos. Ou seja, há a percepção do ácido como substância, mas são ressaltados apenas benefícios e malefícios que ele causar aos cabelos, e isso chama a atenção para um modo de pensar utilitarista/pragmático. De acordo com Mariana, os diferentes produtos usados no salão podem ser diferenciados quanto a sua acidez, basicidade ou neutralidade, dependendo do valor do $\mathrm{pH}$ que eles apresentam. Logo, ainda que não seja medido no salão, o pH tem o valor informado nos rótulos e define alguns usos para os produtos. Ao considerar o valor do $\mathrm{pH}$ dos produtos, um modo de pensar empirista orienta a compreensão da cabeleireira sobre ácido/base. $\mathrm{Na}$ entrevista, podemos verificar que Mariana inverte a convenção que determina o que é ácido $(\mathrm{pH}<7)$ ou básico $(\mathrm{pH}>7)$, no entanto, temos a expectativa de que o uso dos produtos poderá ser feito de maneira apropriada, uma vez que a prática é claramente o que orienta as ações profissionais.

Destacamos, dessa forma, que a cabeleireira Mariana apresenta diferentes modos de pensar ácido/base e que eles não estão estreitamente relacionados com os modelos químicos que explicam o comportamento e propriedade das substâncias ácidas. $\mathrm{O}$ uso do $\mathrm{pH}$ como parâmetro parece aproximar esse conhecimento prático do conhecimento químico, sendo perceptível um esforço de compreensão mais aprofundada sobre os produtos utilizados na prática. No entanto, ainda há uma distância significativa entre esses dois tipos de conhecimento, nesse caso.

A importância do $\mathrm{pH}$ no contexto dos salões de beleza também é enfatizada pela cabeleireira Marília, que é proprietária de um salão de beleza na cidade há mais de 15 anos. De todas as sete cabeleireiras entrevistadas, Marília é a que possui mais experiência no tratamento de cabelos, e isso parece se refletir no maior número de relações semânticas identificadas entre os itens temáticos destacados na sua entrevista. Falas de Marília foram transcritas no Quadro 3. 
Quadro 3. Transcrição de falas e itens temáticos na entrevista com a cabeleireira Marília (ML)

\section{Trechos de falas da cabeleireira Marília na entrevista}

P: 0 que você entende por ácidos?

ML: (...) o que eu entendo por ácidos? (...) é uma química/ na prática é uma coisa e na teoria é outra né? (...) o ácido vem pra / o pH do cabelo é mais neutro entre 6 e 7 nessa faixa/ quando a gente vai trabalhar com ácido o $\mathrm{pH}$ é mais baixo/ o $\mathrm{pH}$ mais alcalino pode chegar até quatorze que é quando a gente trabalha com amônia (...)

P: Como você lida com ácidos no seu dia a dia?

ML: (...) basicamente para tratamento (...) Nas situações das progressivas mesmo/ (...) as progressivas que a gente faz são a base de ácidos (...)

P: Qual é a finalidade especificamente desses produtos?

ML: (...) mas tem alguns produtos que vem tantos por cento mais ácido (...) mas a gente sabe que essas progressivas elas são mais ácidas é que dá mais peso, mais brilho (...) já um produto de luzes (...) já fica o cabelo mais alcalino, tem que vir depois para fazer a reconstrução/ quando é um alisante mesmo a gente tem que fazer a neutralização para neutralizar aquela alcalinidade do cabelo, pra normalizar o fio.

P: $O$ que você entende por $\mathrm{pH}$ ?

ML: (...) é o que mede o potencial hídrico do cabelo, como tá (...) o pH é isso mesmo, é o potencial hídrico do cabelo, água, suor a mistura que dá o equilíbrio (...).

Fonte: Dados da pesquisa

No Quadro 3, destacamos os seguintes itens temáticos na entrevista de Marília: química, pH, cabelo, neutro, ácido, baixo, alcalino, amônia, tratamento, progressivas, produtos, alisante, neutralização, normalizar o fio, potencial hídrico, água, suor. O mesmo procedimento foi realizado para a identificação de relações semânticas e um padrão temático representativo das ideias apresentadas pela cabeleireira Marília é apresentado na Figura 2.

Figura 2: Diagrama de Padrão Temático da cabeleireira Marília

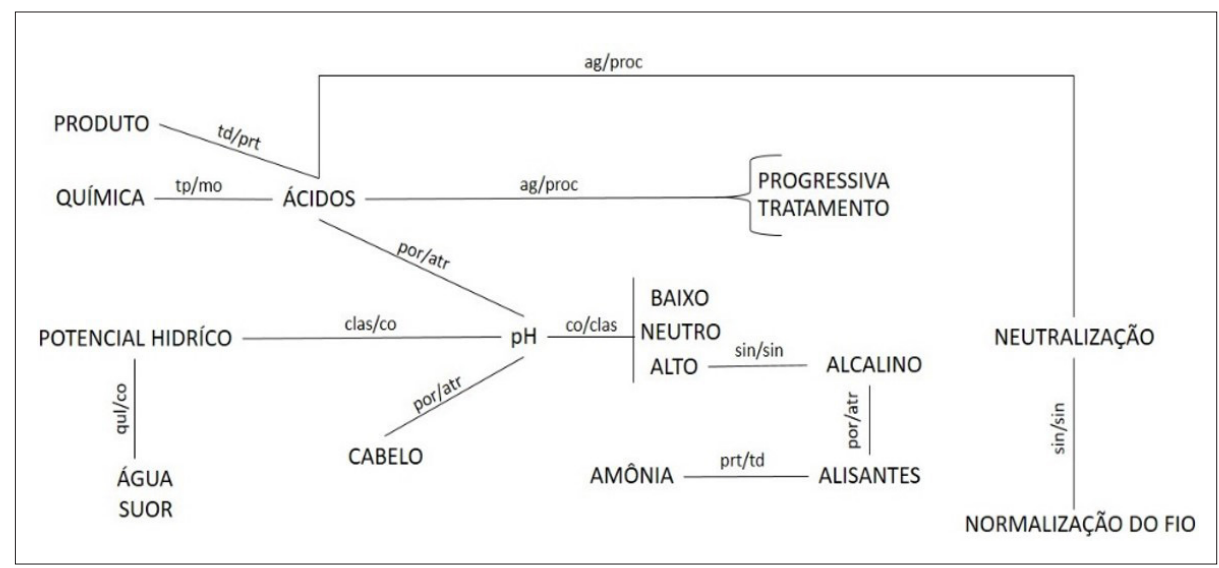

Fonte: Dados da pesquisa. Legenda: por/atr: portador/atributo; ag/proc: agente/processo; co/cla: coisa/classificador; prt/td: parte/todo; tp/mo: tipo/mostra. 
A partir das relações semânticas apresentadas, é possível identificar como o conceito de ácido/base ganha sentido no contexto do trabalho da cabeleireira entrevistada. Marília afirmou que o ácido é uma "química" e que também está presente nos produtos utilizados no salão, caracterizando dois modos de pensar: o primeiro, generalista - quando usou a denominação da ciência química para definir ácido como um tipo de "química". O uso do termo química com esse sentido generalista é comumente encontrado no senso comum. O segundo modo de pensar é substancialista, quando ela sugeriu que os ácidos estão contidos nos produtos, eles são parte dos produtos, deixando implícita a ideia de que eles conferem as suas propriedades aos produtos. Em outro momento, Marília explicou o que entende por ácido a partir da diferenciação entre o que é um ácido utilizando o valor do $\mathrm{pH}$, um atributo dos ácidos, e que pode ser alto, baixo e neutro. Para ela, os ácidos possuem o pH baixo, enquanto a amônia tem um pH alcalino, que pode chegar a 14, e é usada nos produtos com função alisante. Esses parâmetros apontam para um modo de pensar empirista, que novamente aproxima o conhecimento prático do científico, ainda que a cabeleireira tenha se equivocado ao definir pH como "potencial hídrico", quando a definição química do parâmetro é potencial hidrogeniônico. A definição de $\mathrm{pH}$ como potencial hídrico parece estar relacionada com um equilíbrio entre cabelo, água e suor, segundo Marília. Tal como feito por Mariana, Marília se referiu aos ácidos considerando o uso de produtos com finalidades específicas no tratamento de cabelos (escova progressiva, alisamento), também expressando um modo de pensar utilitarista/ pragmático. Podemos verificar na figura 2, que o padrão temático da cabeleireira Marília apresenta maior riqueza de relações semânticas construídas entre padrões temáticos do que o de Mariana. A riqueza de detalhes e uma maior aproximação entre conhecimento prático e aspectos químicos podem estar associadas aos muitos anos de experiência que a cabeleireira tem, o que aponta para uma aprendizagem que se constrói no crescente engajamento e domínio de repertório na comunidade de prática (WENGER, 1998). Nessa direção, os dois padrões temáticos mostrados, e aqueles construídos para as outras 5 cabeleireiras, são representativos de um conhecimento adquirido na prática dessa comunidade, que constitui um domínio compartilhado, principalmente nas interações estabelecidas em salões e em cursos profissionalizantes ou técnicos, pelas diferentes profissionais.

É importante ressaltar que ácidos são componentes ativos de produtos usados no tratamento de cabelos - por exemplo, em escova progressiva e alisamento não permanente - e também é usado para neutralização da amônia que alcaliniza o cabelo nos processos de alisamento e relaxamento, orientados pelo $\mathrm{pH}$. Delfini (2011) destaca que transformações químicas permanentes, colorações, reflexos, entre outros, ocorrem na camada intermediária do cabelo, o córtex, alterando sua estrutura a partir de procedimentos realizados em ambiente com $\mathrm{pH}$ alcalino, por exemplo, o alisamento e relaxamento devem ser feitos em $\mathrm{pH}$ acima de 10 . No processo de alisamento podem ser usadas diferentes substâncias como ácido glioxílico, hidróxido de sódio, hidróxido de guanidina e tioglicolato de amônio.

Podemos verificar que as cabeleireiras aprendem sobre essas características dos produtos e condições de realização dos procedimentos a partir da experiência, e não há indícios de que elas compreendam essas informações em uma visão 
química. Por exemplo, a cabeleireira Marília menciona que os ácidos são usados para neutralização, mas não fica evidente se há uma compreensão da neutralização como uma reação entre ácidos e bases. Dessa forma, nas entrevistas com as cabeleireiras, de uma maneira geral, verificamos uma predominância de modos de pensar ácido/base não necessariamente comprometidos com modelos científicos. $\mathrm{O}$ pH se apresenta como um parâmetro empírico, um atributo que possibilita a classificação de produtos, mas o seu significado químico é pouco ou totalmente desconhecido. Da análise das entrevistas e construção dos diagramas que representam o padrão temático de todas as cabeleireiras, foi possível identificar significados compartilhados em torno do conceito de ácido/base. Nas entrevistas com as cabeleireiras, verificamos que os significados atribuídos para ácidos/bases envolvem principalmente modos de pensar generalista, utilitarista/pragmático, substancialista e empírico. O modo de pensar utilitarista/pragmático parece ter relevância nesse processo uma vez que predomina a constatação de usos e efeitos (benefícios ou malefícios) no reconhecimento dos diferentes produtos usados na prática cotidiana dos salões de beleza. Nessa dinâmica, os modos de pensar racionalista e relacional não emergem na fala das cabeleireiras, ainda que elas não estejam completamente alheias a explicações científicas sobre os produtos utilizados, o que pode ser percebido na emergência de modos de pensar empíricos.

\subsection{Análise dos modos de pensar sobre o conceito de ácido/base expressadas em respostas de licenciandos em química a um questionário}

Os modos de pensar sobre ácido/base expressados por licenciandos em química foram identificados a partir de respostas apresentadas em um questionário. Itens temáticos e relações semânticas foram identificados nas respostas dos licenciandos e padrões temáticos foram construídos para alguns deles, nas respostas para a questão 1 (questão semelhante àquela feita às cabeleireiras, nas entrevistas): $\mathrm{O}$ que você entende por ácido? O que você entende por base? No quadro 4, estão as respostas de 2 licenciandos, escolhidas como representativas das respostas dadas pelos 22 licenciandos.

Quadro 4. Respostas de dois licenciandos à questão $1 \mathrm{e}$ itens temáticos identificados

\begin{tabular}{|c|l|}
\hline Sujeito & Forma de Falar \\
\hline \multirow{3}{*}{ A1 } & $\begin{array}{l}\text { Ácido é uma substância que tem em determinadas situações um comportamento } \\
\text { ácido. Também pode ser entendida do ponto de vista químico como doador de } \\
\text { prótons e receptor de elétrons. Base é uma substância que em determinadas } \\
\text { situações se comporta como base, do ponto de vista químico é doador de elétrons } \\
\text { e receptor de prótons. }\end{array}$ \\
\hline \multirow{2}{*}{ A2 } & $\begin{array}{l}\text { Depende da situação, no contexto científico ácidos e bases são tratados de forma } \\
\text { diferentes, pois existem muitas definições, elas podem aceitar ou doar pares de } \\
\text { elétrons, ou doarem e aceitarem prótons, ou ainda podem atuar apenas em meio } \\
\text { aquoso. No entanto, na aplicação do cotidiano compreendo pelo senso comum } \\
\text { que ácidos são substâncias “azedas" e bases substâncias adstringentes. }\end{array}$ \\
\hline
\end{tabular}

Fonte: Dados da pesquisa 
Da mesma forma como foi feito para as cabeleireiras, relações semânticas foram identificadas para cada um dos licenciandos a partir dos itens temáticos destacados em negrito nas respostas ao questionário.

A visão racionalista atômico molecular é enfatizada na resposta de A1, quando o licenciando se refere a um comportamento ácido/base e aponta características específicas para substâncias ácidas ou alcalinas. O licenciando explica esse comportamento a partir da teoria de Bronsted-Lowry e Lewis, evidenciando a ideia de que ácidos e/ou bases são substâncias que possuem em sua constituição elétrons e prótons que podem ser doados e/ou recebidos. Essas relações semânticas são mostradas na figura 3 .

Figura 3. Diagrama de Padrão Temático do Licenciando A1

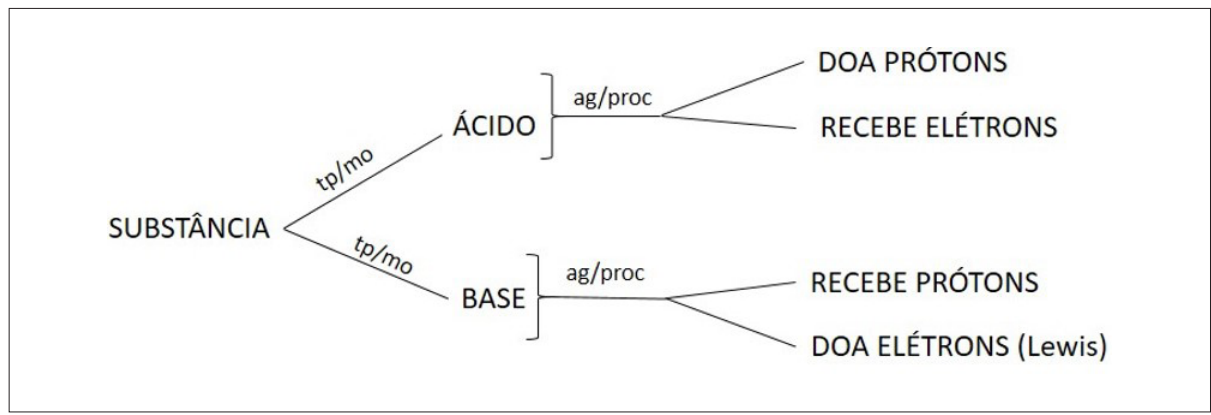

Fonte: Dados da pesquisa

Legenda: tp/mo: tipo/mostra; ag/proc: agente/processo.

Ácidos e/ou bases também podem ser compreendidos por diferentes propriedades que apresentam, e que são estudadas nos contextos acadêmico e escolar, mas algumas delas já são de conhecimento amplo e podem ser identificadas no senso comum. Algumas dessas propriedades são mencionadas nas respostas do licenciando A2 e relações semânticas entre os itens temáticos podem ser vistas na figura 4 .

Figura 4. Diagrama de Padrão Temático do Licenciando A2

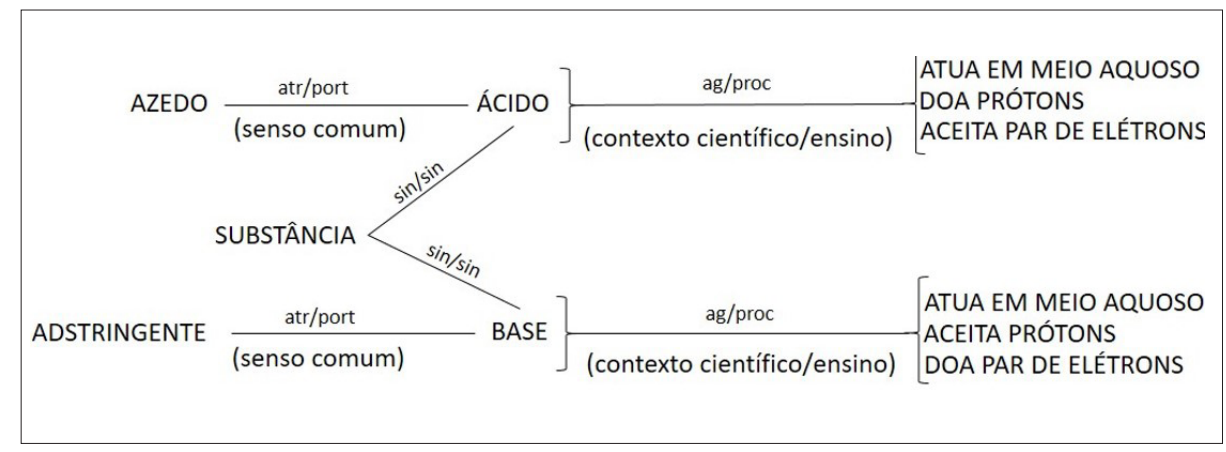

Fonte: Dados da Pesquisa

Legenda: ag/proc: agente/processo; atr/port: atributo/portador; sin/sin: sinônimo. 
Para A2, ácidos são portadores do atributo azedo, enquanto as bases possuem o atributo de adstringente, características também presentes na linguagem do senso comum. Essa ideia sugere um modo de pensar racionalista macroscópico, uma vez que caracteriza ácidos e bases a partir de propriedades sensoriais (azedo, adstringente), que se complementa com uma compreensão de ácidos e bases a partir de modelos científicos. Segundo A2, ácidos e bases são agentes do processo de doar/aceitar prótons, doar/aceitar pares de elétrons, respectivamente, e podem agir em meio aquoso, o que evidencia modos de pensar racionalista atômico molecular, ao diferenciar ácidos e bases a partir de seus constituintes. Além disso, podemos considerar que um modo de pensar relacional pode ser observado uma vez que o licenciando expôs a compreensão da dimensão interativa e circunstancial do comportamento ácido/básico. Um ponto a ressaltar na resposta de $\mathrm{A} 2 \mathrm{diz}$ respeito à consciência que ele demonstra ter, de que existem diferentes modos de pensar sobre ácidos e bases e que eles estão associados a contextos distintos - o senso comum e o científico. Esse é um ponto interessante, uma vez que na perspectiva do perfil conceitual, a aprendizagem ocorre pela tomada de consciência sobre os diferentes modos de pensar os conceitos e os contextos associados aos mesmos (MORTIMER; EL-HANI, 2014).

A análise feita para os licenciandos foi ampliada, e foram encontrados itens temáticos semelhantes na maioria das respostas - substância, doar elétrons, receber elétrons, receber prótons, doar prótons, ácidos e bases - e, dessa forma, foi possível identificar significados compartilhados pelo grupo de licenciandos, no contexto acadêmico. De maneira geral, as respostas dos licenciandos às questões, que compunham a pergunta 2 , foram representativas, um tem uma resposta mais completa, o A1, e outro mais simples, A2, na maioria das respostas encontramos posições intermediárias e mostram uma predominância no uso da linguagem científica relacionada com as diferentes teorias ácido/base que tradicionalmente povoam as salas de aula de química, tanto no Ensino Médio como no Ensino Superior.

As respostas mudam um pouco de padrão quando são colocadas situações nas quais o conceito de ácido/base pode ser aplicado. Na questão 3 - Como os ácidos/bases estão presentes nos contextos de: a) ambientalistas; b) cabeleireiras; c) dermatologistas; d) aula de química do ensino médio - foram analisadas respostas que não necessariamente representam uma explicação científica sobre as substâncias e produtos. Para estabelecer relação entre as respostas dos licenciandos e aquelas obtidas nas entrevistas com as cabeleireiras, neste trabalho, optamos por apresentar a análise feita para as respostas da letra b. No item b, ao analisar como ácidos e bases estão relacionados com o contexto das cabeleireiras, a maior parte dos licenciandos elaborou respostas a partir de exemplos e, em algumas delas, pudemos identificar formas de falar representativas de modos de pensar específicos sobre ácido/base:

"Produtos utilizados para alisamento do cabelo ou tintura de cabelo"; "Estão presentes nos produtos utilizados nos cabelos"; "Os produtos usados nos tratamentos de cabelos devem ter um $\mathrm{pH}$ controlado".

Como a pergunta solicitou que eles respondessem de que forma os ácidos/bases estariam presentes no contexto das cabeleireiras, os exemplos de respostas sugerem uma concepção de ácido/base associada a uma visão 
utilitarista/pragmática, pois os licenciandos afirmam que os ácidos estão presentes no contexto da cabeleireiras ao utilizarem o que eles chamam de produtos.

Verificamos que os licenciandos também apresentaram respostas alinhadas com uma visão científica para o conceito ácido/base, embora outros modos de pensar também tenham emergido nas respostas, como a visão utilitarista/ pragmática. Isso corrobora com o que a teoria do perfil conceitual pressupõe: os indivíduos podem apresentar diferentes modos de pensar e forma de falar sobre um mesmo conceito. Sendo que um ou outro modo de pensar é acessado a depender do contexto/pergunta/problema que se experiencia.

\subsection{Análise de modos de pensar sobre o conceito de ácido/base que emergem nas e a partir das interações entre licenciandos e cabeleireiras}

$\mathrm{Na}$ segunda parte dos resultados e discussão, trazemos a análise de modos de pensar ácido/base que emergem nos relatórios e na apresentação de entrevistas realizadas pelos licenciandos com cabeleireiras, abordando o tema do uso de ácidos e bases no tratamento capilar. É importante destacar que a discussão sobre as entrevistas ocorre no contexto acadêmico, quando eles buscavam compreender e apontar soluções para um caso no qual foi relatada uma situação ocorrida com uso de produtos em um salão de beleza. Inicialmente, analisamos as questões elaboradas pelos licenciandos no planejamento da entrevista que seria feita com os cabelereiros, e aqui focaremos a análise em dois grupos, como já foi mencionado. No quadro 5, são mostradas as questões elaboradas pelos grupos para a entrevista.

Quadro 5. Questões elaboradas pelos grupos 1 e 2 para entrevista com cabeleireiros (as)

\begin{tabular}{|c|l|}
\hline Grupo & \multicolumn{1}{|c}{ Questões } \\
\hline 1 & $\begin{array}{l}\text { 1. Você costuma fazer perguntas sobre quais produtos a cliente usa, e antes } \\
\text { do procedimento realiza um teste de mecha? 2. A amônia e a guanidina são } \\
\text { compatíveis? Explique; 3. O que provoca o corte químico, ou seja, a quebra da } \\
\text { fibra capilar? Como evitar? }\end{array}$ \\
\hline $\mathbf{2}$ & $\begin{array}{l}\text { 1. Se uma cliente chega em seu salão depois de um alisamento, feito por você, } \\
\text { e ela destaca que está com queda de cabelo e estes muito quebradiços, o que } \\
\text { você acha que aconteceu? O que você faria para reverter tal dado? 2. Na sua } \\
\text { opinião qual a diferença que existe entre os tipos de alisamento e os seus } \\
\text { usos em diversos tipos de cabelo? 3. Diante de sua vivência você saberia dizer } \\
\text { quais dos seus produtos são ácidos, quais são básicos? Pra você qual seria a } \\
\text { importância dessa informação? 4. Por que você acredita que procedimentos } \\
\text { químicos sucessivos são prejudiciais ao cabelo? }\end{array}$ \\
\hline
\end{tabular}

Fonte: Dados da pesquisa

No quadro 5, podemos verificar como os licenciandos tentam articular aspectos científicos e procedimentos próprios da prática com tratamento capilar, buscando investigar o nível de compreensão que as cabeleireiras podem apresentar sobre os produtos que utilizam e os procedimentos que realizam. De uma forma geral, nas propostas de questões para as entrevistas, feitas pelos grupos, 
consideramos que houve uma predominância de perguntas relacionadas ao contexto da prática profissional de cabelereiros. Mesmo inseridos em um contexto acadêmico, os licenciandos se preocuparam em buscar informações a respeito de como ocorre o procedimento de alisamento capilar e outros, e questões relativas aos aspectos científicos que podem estar implicados nesses procedimentos foram menos frequentes ou evidentes. O grupo 2 propôs uma única pergunta sobre acidez e basicidade dos produtos. Possivelmente, a não inclusão de perguntas de natureza científica/escolar e/ou utilizando termos associados a esse contexto, se dá pela suposição por parte dos licenciandos de que o grupo entrevistado não tem conhecimento a respeito dos termos científicos associados à temática. Intuitivamente, eles partem de um pressuposto que foi verificado na primeira parte deste trabalho, quando verificamos que há uma apropriação intuitiva ou associada a concepções do senso comum de termos científicos na prática cotidiana das profissionais entrevistadas. No contexto dos salões de beleza, é comum a utilização de termos como ácido, alcalino, neutralização e pH, como foi mostrado anteriormente, o que não representa necessariamente que esses termos sejam compreendidos na perspectiva da química.

Após a elaboração das questões e realização das entrevistas, buscamos identificar como os licenciandos articularam sentidos ou significados compartilhados no contexto da comunidade de prática de cabelereiros(as) com as discussões que eles realizaram no contexto acadêmico. Isso foi feito considerando os dados descritos no relatório elaborado pelos licenciandos e algumas das suas falas, na apresentação dos resultados das entrevistas dos grupos 1 e 2 . O relatório apresentado pelo grupo 1, pode ser visto no Quadro 6:

Quadro 6. Relatório sobre a entrevista realizada com profissional da beleza capilar - Grupo 1

Foi realizada uma entrevista com uma cabeleireira, com aproximadamente 20 anos de experiência, com as seguintes perguntas: 1. Você costuma fazer perguntas sobre quais produtos a cliente usa, e antes do procedimento realiza um teste de mecha? 2. A amônia e a guanidina são compatíveis? Por que? 3. 0 que provoca o corte químico, ou seja, a quebra da fibra do cabelo? Com relação as perguntas feitas, obtivemos as seguintes respostas: 1. "Pergunto o que ela usa, principalmente se for uma cliente que vem pela primeira vez, tem que saber o que ela usa e se for uma química tem que fazer um teste de mecha, para ver se o cabelo resiste." 2. “Nunca, se colocar amônia e guanidina a pessoa fica careca na hora, porque são duas fórmulas diferentes e não se batem de jeito nenhum." 3. “Depende da cliente, às vezes é problema de hormônios e às vezes de produtos químicos, quando o cabelo quebra por conta de problemas no organismo pode estar relacionado a anemia, tireoide ou por falta de vitaminas. Quando é por causa da química é por conta de produtos que não são compatíveis. Para evitar, basta não usar, se for por conta do organismo a cliente deve ir ao dermatologista para saber a causa do problema". Percebemos a partir da fala da cabeleireira que a mesma possui um certo conhecimento da sua área de profissão, no entanto, percebe-se em suas respostas maior domínio em relação ao conhecimento prático (senso comum) do que aos conhecimentos científicos. Diante da entrevista realizada podemos concluir que boa parte das respostas dadas por ela estão relacionadas com as possíveis soluções que já havíamos sugerido para o caso, no entanto, ela destacou um ponto que não havíamos discutido relacionado a questão da saúde (hormonal, anemia, tireoide e falta de vitaminas no organismo).

Fonte: Dados da pesquisa 
Conforme relatório apresentado, no Quadro 6, o grupo apresentou todas as respostas dadas pela entrevistada e ao final teceu alguns comentários sobre elas, afirmando que a profissional possuía bom conhecimento sobre sua área de atuação. É possível observar que as perguntas feitas pelo grupo envolvem aspectos da prática profissional. O grupo pergunta sobre o teste de mecha, ${ }^{2}$ incompatibilidade entre produtos para alisamento e corte químico, e todos esses termos e expressões fazem parte do repertório ou domínio da comunidade de prática de cabelereiros, expressados em linguagem específica para quem lida com tratamento de cabelos. Isso fica evidente quando percebemos a familiaridade com a qual a cabeleireira trata desses temas. Uma particularidade é ressaltada pelos licenciandos no relatório quando a entrevistada se refere à possível relação entre hormônios e a ocorrência de corte químico nos cabelos. A cabeleireira sugere que a quebra do cabelo pode acontecer também por conta da falta de vitaminas e/ou problemas na tireóide. Na segunda questão, é feita referência a substâncias químicas, mas em um sentido amplo e generalista - são "fórmulas diferentes e não batem...", sem maiores explicações sobre suas características, propriedades ou constituição (modo de pensar generalista). A surpresa dos licenciandos parece estar associada ao fato de a cabeleireira usar uma justificativa que tem base em conhecimentos formais para tentar explicar a ocorrência de alguns problemas com os cabelos. Esse tipo de conhecimento não parece associado diretamente à prática profissional, mas oriundo de experiências pessoais, o que inclui algum tipo de formação, ou troca de experiências com outras pessoas.

De uma forma geral, nas respostas obtidas pelos licenciandos nas entrevistas, houve predominantemente o uso da linguagem específica da comunidade de prática, talvez devido à forma como os grupos elaboraram as questões, mas também considerando que essa linguagem é aquela na qual o domínio da comunidade se constitui.

Ao analisarmos o relatório do grupo 2, observamos que as perguntas elaboradas envolvem tanto aspectos relacionados à prática profissional de cabelereiros como termos usados no contexto científico/escolar. Segundo consta no relatório, que não apresentaremos na íntegra por questões de espaço, a cabeleireira entrevistada atribui importância ao conhecimento sobre os tipos de cabelo ou fio que as clientes apresentam quando chegam ao salão com demanda de tratamento e para o uso de produtos. Nas duas primeiras questões sobre alisamento e queda do cabelo, e sobre diferenças entre tipos de alisamento, os licenciandos parecem ter a intenção de obter informações sobre o caso a ser solucionado, ou seja, eles buscam na experiência prática maior compreensão sobre a situação descrita no estudo de caso. $\mathrm{Na} 3^{\mathrm{a}}$ questão, eles parecem querer sondar sobre as relações estabelecidas entre o conhecimento prático e científico pela cabeleireira, buscando conhecer os sentidos ou significados atribuídos ao conceito de ácido/base no contexto investigado. Nas respostas às duas primeiras questões, a cabeleireira se refere a características dos produtos ou adequação dos tratamentos levando em conta a estrutura do fio ou o tipo do cabelo - ela mencionou o nome químico das substâncias que compõem os produtos e apontou para tratamentos mais ou menos agressivos aos cabelos associados ao uso dessas substâncias. Nesse sentido, a cabeleireira parece apresentar um modo de pensar utilitarista/pragmático nessas respostas. Com relação à terceira 
questão, ao ser questionada sobre o pH, a entrevistada associou esse parâmetro ao uso dos produtos para abrir ou fechar as cutículas do cabelo, evidenciando o uso e função dos produtos, em detrimento da composição ou característica que apresentam. Nesse caso, a acidez/basicidade é relacionada com a medida de $\mathrm{pH}$, o que aponta para um movimento entre modos de pensar utilitarista/pragmático e empírico. Ela menciona que estudou sobre $\mathrm{pH}$ no curso técnico, mas que esse parâmetro é muitas vezes negligenciado na prática, demonstrando uma tentativa de recuperar conhecimentos formais para responder à questão feita.

\section{CONSIDERAÇÕES FINAIS}

Ao analisar concepções de licenciandos e cabeleireiras sobre ácidos e bases, podemos constatar que ambos apresentam diferentes modos de pensar sobre esses conceitos que emergem associados aos contextos aos quais eles se referem. Os licenciandos, nas respostas ao questionário, usaram predominantemente uma linguagem científica para elaborar suas respostas, principalmente na primeira questão analisada e isso ficou evidenciado nos diagramas temáticos. Diferentes sentidos foram identificados, mas todos carregavam uma forte influência do contexto científico, que emergiram em modos de pensar utilitarista/pragmático, racionalista, empirista e relacional. Com relação às cabeleireiras, os diagramas temáticos mostraram sentidos e significados compartilhados na comunidade de prática e foram identificados modos de falar generalista, utilitarista/pragmático, substancialista e empirista. Identificamos itens temáticos mais alinhados com a linguagem cotidiana e as relações semânticas apontavam para significados relacionados às práticas do grupo.

Esses resultados apontam para reflexões sobre as relações entre conhecimentos e contextos: a) É esperado que os licenciandos apresentem predominantemente modos de pensar científicos, no contexto acadêmico, e que as cabeleireiras demonstrem domínio de um conhecimento prático, com limitadas inserções de modelos científicos. No entanto, os dois grupos de sujeitos apresentam modos de pensar utilitarista/ pragmático e empírico - relacionados à aplicação do conceito - quando é feita uma aproximação de contextos, no processo de construção de significados; b) A aproximação de contextos parece nos levar a situar ou (re) dimensionar a maior ou menor aplicabilidade dos modelos científicos em algumas práticas - aparentemente, a ausência ou limitação de conhecimento científico não interfere sobremaneira na prática das cabeleireiras - e a questionar a validade, alcance ou eficiência de conhecimentos exclusivamente práticos, quando somos desafiados a resolver problemas complexos. Ao buscar resolver um problema real, sobre o uso de produtos químicos no cabelo, os licenciandos buscaram aspectos do conhecimento prático como forma de complementar a compreensão dos modelos teóricos, e ao buscar razões para os efeitos indesejáveis de produtos, as cabeleireiras tentaram recorrer a conhecimentos mais elaborados; c) o deslocamento dos licenciandos do contexto da sala de aula para o contexto das cabeleireiras trouxe desafios para a articulação entre conhecimentos científicos e práticos, e parece resultar em um potencial entrelaçamento de sentidos e significados.

De uma maneira geral, é importante ressaltar que a associação do 
conceito com questões presentes em contextos sociais parece suscitar modos de pensar que se constituem na relação dos sujeitos com situações vivenciadas, que não necessariamente demandam uma compreensão científica de conceitos ou temáticas. A análise ainda aponta para a importância de uma contextualização profunda nos espaços formativos, no sentido de promover maior significação para os conhecimentos científicos, como instrumento de compreensão e transformação do mundo em que vivemos, que necessariamente devem ser articulados a outras formas de conhecimento. $\mathrm{E}$, os perfis conceituais podem ser uma ferramenta poderosa no processo de articulação desses conhecimentos.

\section{REFERÊNCIAS}

AMARAL, E. M. R.; MORTIMER, E. F. Un perfil conceptual para entropia y espontaneidad: una caracterizacion de las modos de pensar y hablar en el aula de química. Educacion química, n. 3, p. $60-75.2004$.

AMARAL, E.M.R.; MORTIMER, E.F. Uma proposta de perfil conceitual para o conceito de calor. Revista Brasileira de Pesquisa em Educação em Ciências. Belo Horizonte. v. 1 n. 3 p. 1-16. 2001.

ARAÚJO, A. O. O perfil conceitual de calor e sua utilização por comunidades situadas. 2014. 223 f. Tese (Doutorado) - Programa de Pós-graduação em Educação, Universidade Federal de Minas Gerais, Belo Horizonte. 2014.

ARAÚJO, A. O.; MORTIMER, E. F. Estudo preliminar sobre a utilização do perfil conceitual de calor em um curso para manutenção e instalação de aparelhos de refrigeração. Anais do Encontro Nacional de Ensino de Química (ENEQ), UFBA. 2012.

BARDANCA, M.; NIETO, M.; RODRIGUEZ, M.C. Evolución de los conceptos Ácido-base a lo largo de la ensenanza media. Investigacion y experiencias didácticas, v. 11, n. 2, pp. 125-129. 1993.

CARDOSO, S. M. B.; SILVA, L. H. B.; LIMA, J. P. M. Concepções alternativas de estudantes da $1^{\circ}$ série do ensino médio sobre ácidos e bases investigadas nas ações do PIBID/Química/UFS/São Cristóvão. Scientia Plena, v. 10, n. 08. 2014.

COLL, C.; BUSTOS, A.; ENGEL, A. As comunidades virtuais de aprendizagem. In: COLL, C. et al. Psicologia da educação virtual. Aprender e ensinar com as tecnologias da informação e da comunicação. Porto Alegre: Artmed, p. 268-286. 2010.

COUTINHO, F. A; EL-HANI; C. N.; MORTIMER; E. F. Building a Profi le for the Biological Concept of Life. In: Bases of a Research Program Conceptual Profiles: A Theory of Teaching and Learning Scientific Concepts. New York: Spriger. 2014.

CYRINO, M. C. C. T; CALDEIRA, J. S Processos de negociação de significados sobre pensamento algébrico em uma CoP de formação inicial de professores de matemática. Investigações em Ensino de Ciências - V16(3), pp. 373-401. 2011.

DELFINI, F. N. A. Trabalho de Conclusão de Curso - Ativos alisantes em cosméticos. Monografia (Graduação). UNESP, Araraquara, 53 p. 2011.

EL-HANI, C.; GRECA, I. M. Participação em uma comunidade virtual de prática desenhada como meio de diminuir a lacuna pesquisa-prática na educação em Biologia. Ciência e Educação, v. 17, n.3, p. 579- 601. 2011. 
FIGUEIRA, A. C. M.; OLIVEIRA, A. M.; SALLA, L. F.; ROCHA, J. B. T. Concepções alternativas de estudantes do ensino médio: ácidos e bases. In: Anais do VII Encontro Nacional de Pesquisa em Educação em Ciências (VII ENPEC), Florianópolis, nov. 2009.

FIGUEIRA, A. C. M.; ROCHA, J. B. T (2011). Investigando as concepções dos estudantes do ensino fundamental ao superior sobre ácidos e bases. Revista Ciências\&Ideias, v. 3, n. 1.

LEMKE, J. Aprender a Hablar Ciência. Lenguaje, Aprendizaje y Valores. $1^{\mathrm{a}}$ ed. Barcelona: Paidós. 1997.

MORTIMER, E. F. Construtivismo, mudança conceitual e ensino de ciências: para onde vamos? Investigações em ensino de ciências, 1(1), p. 20-39. 1996.

MORTIMER, E. F; SCOTT, P; EL-HANI, C. N. Bases teóricas e epistemológicas da abordagem dos perfis conceituais. Tecné, Episteme y Didaxis, n.30, p.111-125. 2011.

OLIVEIRA, A. M. Concepções alternativas de estudantes do ensino médio sobre ácidos e bases: um estudo de caso. Dissertação (Mestrado), 71 p., Porto Alegre-RS. 2008.

PETRY, D. Tioglicolato de amônio: avaliação in vitro de liberação, atividade antioxidante e geração de resíduos. Dissertação (Mestrado) - Programa de pós-graduação em ambiente em desenvolvimento, UNIVATES, Lajeado, 2013.

RAMOS, W. R.; MANRIQUE, A. L. Comunidades de prática de professores que ensinam matemática como espaço de negociações de significados sobre a resolução de problemas. Bolema, Rio Claro (SP), v. 29, n. 53, p. 979-997. 2015.

SABINO, J. D.; AMARAL, E. M. R. Utilização do perfil conceitual de substância no planejamento do ensino e na análise do processo de aprendizagem. Investigações em Ensino de Ciências, v. 23, n. 1 , p. $245-265.2018$

SANTOS, V. C. A formação de professores em comunidades de prática: o caso de um grupo de professores de química em formação inicial. 2015. 452 f. Tese (Doutorado) - Programa de Pósgraduação Interunidades em Ensino de Ciências, Universidade de São Paulo, São Paulo. 2015.

SEPULVEDA, C.; EL-HANI, C.N. Prática de ensino e estágio supervisionado como participação em CoP: examinando uma proposta para licenciaturas em ciências. In: Atas do IX Encontro Nacional de Pesquisa em Educação em Ciências. Rio de Janeiro: ABRAPEC. 2013.

Silva, F. C. V.; Amaral, E. M. R Tendências de pesquisa, concepções de estudantes e desenvolvimento histórico do conceito de ácido. In: XVII Encontro Nacional de Ensino de Química (XVII ENEQ), Ouro Preto-MG, Atas do XVII ENEQ. 2014.

SILVA, F.C.V. Análise de diferentes modos de pensar e formas de falar o conceito de ácido/ base em uma experiência socialmente situada vivenciada por licenciandos em química. 2017. 241 f. Tese (Doutorado) - Curso de Ensino das Ciências, Universidade Federal Rural de Pernambuco, Recife. 2017b.

SILVA, J. R. R. T. Um Perfil Conceitual para o Conceito de Substância. Recife, 2011. 186 p. Dissertação (Mestrado em Ensino das Ciências). Departamento de Educação, Universidade Federal Rural de Pernambuco.

SILVA, J. R. R. T. Diversos modos de pensar o conceito de substância química na história da ciência e sua visão relacional. Ciência \& Educação, Bauru, v. 23, n. 3, p. 707-722. 2017ª . 
SILVA, J. R. R. T.; AMARAL, E.M.R. Proposta de um perfil conceitual para substância. Revista Brasileira de Pesquisa em Educação em Ciências. v. 13, n. 3. 2013.

WENGER, E. Communities of practice: learning, meaning, and identity. Cambridge University Press. 1998.

\section{NOTAS}

1 Optamos por utilizar apenas o termo "ácido" no contexto da comunidade de prática, por questões de ordem prática, uma vez que, no cotidiano/contextos não escolares/acadêmicos, o termo ácido é usado mais frequentemente. Ao longo da entrevista observamos que o termo "alcalino" também faz parte da linguagem especializada da comunidade de prática investigada.

2 Na prática de profissionais da beleza capilar, quando dois produtos não compatíveis são utilizados no mesmo cabelo, sem intervalo recomendado, ocorre o chamado corte químico ou choque químico. Para que isso não ocorra, é recomendado o teste de mecha, que possibilita ao profissional identificar o tempo de ação do produto quando aplicado no cabelo (PETRY, 2013)

Submetido em 22/02/2020

Aprovado em 15/05/2020

\section{Contato:}

Universidade Federal Rural de Pernambuco | Unidade Acadêmica de Serra Talhada

Flávia Cristiane Vieira da Silva

Av. Gregório Ferraz Nogueira, S/N - José Tomé de Souza Ramos

CEP 56.909-535 - Serra Talhada, PE - Brasil

Caixa Postal: 063 